\title{
Effect of pappus removal on seed germination in Solidago xniederederi (Asteraceae) and closely related species
}

\author{
Artur Pliszko $^{1}$ (D) K Kinga Kostrakiewicz-Gierałt ${ }^{2}$ (D) \\ Received: 21 February 2020 / Accepted: 21 April 2020 / Published online: 4 May 2020 \\ (C) The Author(s) 2020
}

\begin{abstract}
In Solidago, the pappus, a modified calyx, protects ovary and fruit from predation and is strongly involved in anemochory. In this study, we aimed to test the hypothesis that the mechanical removal of pappus decreases the final percentage and speed of seed germination. We examined $S$. ×niederederi, a natural hybrid between invasive $S$. canadensis and native $S$. virgaurea, in comparison to its parental species and $S$. gigantea. We conducted a 21-day germination test in the laboratory, using 50 fruits with intact pappus and 50 fruits with removed pappus in four replicates, for each taxon. The statistical analysis demonstrated that the final percentage of germinated seeds was remarkably lower in the group of fruits with removed pappus in $S$. canadensis $(p \leq 0.05)$ and $S$. gigantea $(p \leq$ $0.05)$. Moreover, the speed of seed germination was also significantly lower after pappus removal in $S$. canadensis and $S$. gigantea, based on the Timson's index $(p \leq 0.05)$. In the case of $S$. × niederederi and $S$. virgaurea, the hypothesis was rejected. We assumed that the small size of the cypselae could be responsible for the negative effect of pappus removal on seed germination.
\end{abstract}

Keywords Alien species $\cdot$ Hybrid $\cdot$ Pappus $\cdot$ Seed germination test $\cdot$ Solidago $\cdot$ Timson's index

\section{Introduction}

The pappus, a modified calyx, plays a major role in the protection of the ovary and dispersal of fruits in Asteraceae. It protects the ovary and fruit from predation and is involved in anemochory and zoochory (Mukherjee and Nordenstam 2008 and references therein). Moreover, the structure and arrangement of pappus elements have long been used to delimit tribes, genera and other taxa in Asteraceae (Small 1918; Nesom 1993, 2000; Mukherjee and Nordenstam 2008; Marzinek and Oliveira 2010; Frangiote-Pallone and de Souza 2014; Talukdar 2015; Silva et al. 2018). Interestingly, Shaukat et al. (2004) evidenced that the removal of pappus decreases the final percentage of seed germination due to decreased hydration of the fruits in Vernonia cinerascens Sch.

Artur Pliszko

artur.pliszko@uj.edu.pl

1 Department of Taxonomy, Phytogeography and Palaeobotany, Institute of Botany, Faculty of Biology, Jagiellonian University, Gronostajowa 3, 30-387 Kraków, Poland

2 Department of Tourism Geography and Ecology, Institute of Tourism, Faculty of Tourism and Recreation, University of Physical Education in Krakow, Jana Pawła II 78, 31-571 Kraków, Poland
Bip. and V. cinerea (L.) Less. Similarly, Hale et al. (2010) proved that in the fruits with removed pappus seed germination was $31 \%$ lower than in the fruits with intact pappus in Taraxacum officinale F.H. Wigg.

The genus Solidago L. comprises about 133 species and is native to North America, South America, Europe and Asia (Semple and Cook 2006; Semple 2020). In Solidago, the pappus is strongly involved in anemochory and consists of barbellate bristles which can be arranged in 1-3 whorls (Hood and Semple 2003). However, there is a lack of studies that could explain the role of pappus in seed germination in this genus. Solidago $\times$ niederederi Khek, a natural hybrid between the North American $S$. canadensis L. and the European $S$. virgaurea (Pliszko 2015; Karpavičienè and Radušienė 2016; Pliszko and Zalewska-Gałosz 2016; Radušienè et al. 2018), occurs in several countries in Europe and is treated as an alien taxon (Pliszko and Kostrakiewicz-Gierałt 2017b; Jaźwa et al. 2018). It occupies anthropogenic habitats such as abandoned fields, roadsides, railway embankments, disused quarries, tree plantations, forest clearings, and tracks, usually together with its parental species (Nilsson 1976; Burton 1980; Sunding 1989; Stace et al. 2015; Gudžinskas and Petrulaitis 2016; Pliszko and KostrakiewiczGierałt 2017b; Pliszko et al. 2017, 2019). Similarly to $S$. canadensis and $S$. virgaurea, the hybrid is a perennial plant and spreads by wind-dispersed fruits (cypselae) (Pliszko and 
Table 1 Description of seed germination parameters

\begin{tabular}{|c|c|c|}
\hline Parameter & Formula for calculation & Description \\
\hline Timson's index & $\Sigma \mathrm{n}$ & $\begin{array}{l}n \text { - cumulative daily germination percentage } \\
\text { for each day of the test }\end{array}$ \\
\hline mean germination time & $\Sigma\left(\mathrm{n}_{\mathrm{i}} \times \mathrm{d}_{\mathrm{i}}\right) / \mathrm{N}$ & $\begin{array}{l}\mathrm{n}_{\mathrm{i}}-\text { number of seeds germinated at day } \mathrm{d}_{\mathrm{i}}, \\
\mathrm{N} \text { - total number of seeds germinated in the test }\end{array}$ \\
\hline coefficient of velocity & $\begin{array}{l}100\left(A_{1}+A_{2}+\ldots+A_{x}\right) / \\
\left(A_{1} T_{1}+A_{2} T_{2}+\ldots+A_{x} T_{x}\right)\end{array}$ & $\begin{array}{l}A_{1}+A_{2}+\ldots+A_{x}-\text { number of seeds germinated on } \\
\text { the first, second and final days that seedlings appeared, } \\
T_{1}, T_{2} \text { and } T_{x}-\text { number of days between sowing and first, } \\
\text { second and final times that seedlings were recorded }\end{array}$ \\
\hline
\end{tabular}

Kostrakiewicz-Gierałt 2017b, 2019). However, the production of fruits in $S$. $\times$ niederederi is usually limited by its reduced pollen viability (Migdałek et al. 2014; Karpavičienè and Radušienè 2016). On the other hand, there is a probability that the hybrid produces the fruits by backcrossing with $S$. canadensis and $S$. virgaurea (Pagitz 2016). According to Pliszko and Kostrakiewicz-Gierałt (2017a, 2017b, 2018a), seeds of $S$. $\times$ niederederi can achieve a high percentage of germination and cold stratification is not obligatory to break their dormancy. Since the hybrid has the potential to be established and poses a threat by competing with native species for insect pollinators and other resources (Pliszko and Kostrakiewicz-Gierałt 2017b, 2018b, 2019; Jaźwa et al. 2018), the studies on its ecology are needed.

In this study, we focused on the effect of pappus removal on seed germination in $S$. ×niederederi and its parental species. We also included $S$. gigantea Ait., a North American species closely related to $S$. canadensis. We aimed to test the hypothesis that the mechanical removal of pappus decreases the final percentage and speed of seed germination.

\section{Materials and methods}

\section{Fruit sampling and measurements}

Fruits (cypselae) of Solidago $\times$ niederederi, S. canadensis, $S$. virgaurea, and $S$. gigantea, were collected from natural populations (one population per taxon) occurring on abandoned fields near Palcza (GPS coordinates: $49^{\circ} 48.500^{\prime} \mathrm{N} /$ $19^{\circ} 45.187^{\prime} \mathrm{E} ; 49^{\circ} 48.755^{\prime} \mathrm{N} / 19^{\circ} 45.405^{\prime} \mathrm{E}$; altitude: $496-$ $546 \mathrm{~m}$ a.s.1.), southern Poland, on 27 October 2018. The populations of $S$. canadensis, $S$. virgaurea, and $S$. gigantea were isolated from each other by a distance of at least $100 \mathrm{~m}$. Due to difficulties in finding a well-isolated population of $S$. $\times$ niederederi we selected the $\mathrm{F}_{1}$ generation hybrids which occurred at a distance of at least $10 \mathrm{~m}$ from both parental species. For each taxon, ten panicles with mature fruits were randomly sampled and transported to the laboratory. In the laboratory, the panicles were kept at room temperature $\left(+25^{\circ} \mathrm{C}\right)$ for 5 days to dry. Next, the panicles were threshed manually to obtain the samples of fruits for further investigation. The samples of 50 well-developed fruits of each taxon were selected for measurements using a Nikon SMZ1500 stereomicroscope. The measurements included the length and the width of the cypselae (fruit body excluding the pappus), as well as the number and the length of the pappus bristles, and only one randomly selected pappus bristle from the inner whorl of each fruit was measured. The width was measured at the top of the cypsela, in the area where the fruit is the widest. For each taxon, the samples of 200 fruits whose pappus had been removed mechanically and the samples of 200 fruits with intact pappus as a control group were used for a seed germination test. The pappus bristles were carefully separated from the cypselae using the tweezers and Nikon

Table 2 Differences in the mean values $( \pm \mathrm{SD})$ of selected fruit morphological traits between Solidago $\times$ niederederi, S. canadensis, S. virgaurea, and S. gigantea $(n=50)$

\begin{tabular}{lllll}
\hline Taxon & Number of pappus bristles & Length of pappus bristle $(\mathrm{mm})$ & Length of cypsela (mm) & Width of cypsela (mm) \\
\hline Solidago $\times$ niederederi & $39.5( \pm 6.0)^{\mathrm{b}}$ & $2.8( \pm 0.6)^{\mathrm{b}}$ & $1.8( \pm 0.2)^{\mathrm{c}}$ & $0.5( \pm 0.0)^{\mathrm{a}}$ \\
Solidago canadensis & $24.9( \pm 3.6)^{\mathrm{a}}$ & $1.9( \pm 0.3)^{\mathrm{a}}$ & $1.1( \pm 0.1)^{\mathrm{a}}$ & $0.4( \pm 0.4)^{\mathrm{a}}$ \\
Solidago virgaurea & $65.7( \pm 7.1)^{\mathrm{c}}$ & $4.0( \pm 0.6)^{\mathrm{c}}$ & $2.4( \pm 0.2)^{\mathrm{d}}$ & $0.7( \pm 0.1)^{\mathrm{c}}$ \\
Solidago gigantea & $41.4( \pm 5.0)^{\mathrm{b}}$ & $2.8( \pm 0.4)^{\mathrm{b}}$ & $1.6( \pm 0.2)^{\mathrm{b}}$ & $0.5( \pm 0.0)^{\mathrm{a}}$ \\
Statistical significance level & $\mathrm{F}=378.9 ;$ & $\mathrm{F}=158.7 ;$ & $\mathrm{F}=396.7 ;$ & $\mathrm{F}=8.2 ;$ \\
& $p<0.001$ & $p<0.001$ & $p<0.001$ & $p<0.001$ \\
\hline
\end{tabular}

The diverse letters in superscript indicate the significant differences (Tukey post-hoc test) between the taxa 
Table 3 Differences in the mean values $( \pm \mathrm{SD})$ of final percentage of germinated seeds between Solidago $\times$ niederederi, S. canadensis, S. virgaurea, and $S$. gigantea, in the groups of fruits with intact and removed pappus, on the basis of four replicates of 50 fruits

\begin{tabular}{llll}
\hline Experimental group & Taxon & $\begin{array}{l}\text { Final percentage of } \\
\text { germinated seeds }\end{array}$ & $\begin{array}{l}\text { Statistical significance level } \\
\text { (Kruskal-Wallis H test) }\end{array}$ \\
\hline Fruits with intact pappus & Solidago $\times$ niederederi & $67.0( \pm 5.0)^{\mathrm{ab}}$ & $\mathrm{H}=12.6 ;$ \\
& Solidago canadensis & $60.0( \pm 2.8)^{\mathrm{a}}$ & \\
& Solidago virgaurea & $71.0( \pm 5.0)^{\mathrm{ab}}$ & \\
& Solidago gigantea & $91.0( \pm 3.5)^{\mathrm{b}}$ & $\mathrm{H}=11.3 ;$ \\
Fruits with removed pappus & Solidago $\times$ niederederi & $64.5( \pm 9.3)^{\mathrm{ab}}$ & $p \leq 0.05$ \\
& Solidago canadensis & $47.5( \pm 1.9)^{\mathrm{a}}$ & $82.0( \pm 9.1)^{\mathrm{b}}$ \\
& Solidago virgaurea & $68.5( \pm 7.2)^{\mathrm{ab}}$ & \\
\hline
\end{tabular}

The diverse letters in superscript indicate the significant differences between the taxa

SMZ1500 stereomicroscope to avoid the inclusion of fruits whose pericarp was damaged by removing the pappus. The accuracy of pappus removal and a lack of damage to the fruit body were checked using the Nikon SMZ1500 stereomicroscope. The studied taxa were identified based on morphological characters provided by Nilsson (1976), Karpavičienè and Radušienè (2016), and Gudžinskas and Žalneravičius (2016).

\section{Seed germination test}

Sets of 50 fruits of Solidago ×niederederi, S. canadensis, S. virgaurea, and $S$. gigantea in four replicates were placed on filter paper in $90 \mathrm{~mm}$ polystyrene Petri dishes. Next, the fruits were wetted using $2.5 \mathrm{ml}$ of distilled water and the moisture inside the Petri dishes was maintained by the addition of $1 \mathrm{ml}$ of distilled water every other day of the germination test period. The samples were kept at room temperature $\left(+25^{\circ} \mathrm{C}\right)$ under a 12 -h photoperiod $(630 \mathrm{~lx})$. The germination test lasted 21 days and the fruits were checked in one-day intervals. The seed included in the cypsela was determined as germinated when the pericarp of the cypsela was broken and the length of the emerging radicle, hypocotyl or cotyledons was at least $1 \mathrm{~mm}$.

\section{Germination parameters}

The speed of seed germination was estimated using the Timson's index (Timson 1965), the mean germination time (Orchard 1977), and the coefficient of velocity (Baskin and Baskin 2014). The formulas of germination parameters are explained in Table 1. The Timson's index was calculated for a 10-day seed germination test period, whereas the mean germination time and the coefficient of velocity were calculated for a total time of seed germination test period ( 21 days). The fast seed germination is indicated by the high values of Timson's index and coefficient of velocity as well as by the low value of the mean germination time (Al-Mudaris 1998; Baskin and Baskin 2014; Pliszko and Kostrakiewicz-Gierałt 2017a, 2017b, 2018a).

\section{Statistical analysis}

Due to a low number of replicates in the seed germination experiment the statistical analysis of germination parameters was based on the non-parametric tests. The Kruskal-Wallis $\mathrm{H}$ test was applied to check the statistical significance of

Table 4 Differences in the mean values $( \pm \mathrm{SD})$ of Timson's index between Solidago $\times$ niederederi, S. canadensis, S. virgaurea, and S. gigantea, in the groups of fruits with intact and removed pappus, on the basis of four replicates of 50 fruits

\begin{tabular}{|c|c|c|c|}
\hline Experimental group & Taxon & Timson's index & $\begin{array}{l}\text { Statistical significance level } \\
\text { (Kruskal-Wallis H test) }\end{array}$ \\
\hline \multirow[t]{3}{*}{ Fruits with intact pappus } & $\begin{array}{l}\text { Solidago } \times \text { niederederi } \\
\text { Solidago canadensis }\end{array}$ & $\begin{array}{l}472.5( \pm 44.9)^{\mathrm{ab}} \\
411.0( \pm 17.6)^{\mathrm{a}}\end{array}$ & \multirow[t]{3}{*}{$\begin{array}{l}\mathrm{H}=10.7 \\
p \leq 0.05\end{array}$} \\
\hline & Solidago virgaurea & $418.5( \pm 8.5)^{\mathrm{a}}$ & \\
\hline & Solidago gigantea & $650.5( \pm 40.4)^{\mathrm{b}}$ & \\
\hline \multirow[t]{3}{*}{ Fruits with removed pappus } & $\begin{array}{l}\text { Solidago } \times \text { niederederi } \\
\text { Solidago canadensis }\end{array}$ & $\begin{array}{l}473.0( \pm 50.2)^{\mathrm{ab}} \\
325.5( \pm 37.5)^{\mathrm{a}}\end{array}$ & \multirow[t]{3}{*}{$\begin{array}{l}\mathrm{H}=10.5 \\
p \leq 0.05\end{array}$} \\
\hline & Solidago virgaurea & $544.0( \pm 50.4)^{\mathrm{b}}$ & \\
\hline & Solidago gigantea & $493.0( \pm 53.7)^{\mathrm{ab}}$ & \\
\hline
\end{tabular}

The diverse letters in superscript indicate the significant differences between the taxa 
Table 5 Differences in the mean values $( \pm \mathrm{SD})$ of mean germination time between Solidago $\times$ niederederi, $S$. canadensis, $S$. virgaurea, and S. gigantea, in the groups of fruits with intact and removed pappus, on the basis of four replicates of 50 fruits

\begin{tabular}{|c|c|c|c|}
\hline Experimental group & Taxon & $\begin{array}{l}\text { Mean germination } \\
\text { time }\end{array}$ & $\begin{array}{l}\text { Statistical significance level (Kruskal- } \\
\text { Wallis H test) }\end{array}$ \\
\hline \multirow[t]{4}{*}{$\begin{array}{l}\text { Fruits with intact } \\
\text { pappus }\end{array}$} & $\begin{array}{l}\text { Solidago } \\
\quad \times \text { niederederi }\end{array}$ & $4.0( \pm 0.2)^{\mathrm{ab}}$ & \multirow{4}{*}{$\begin{array}{l}\mathrm{H}=9.5 \\
p \leq 0.05\end{array}$} \\
\hline & $\begin{array}{l}\text { Solidago } \\
\quad \text { canadensis }\end{array}$ & $4.1( \pm 0.1)^{\mathrm{ab}}$ & \\
\hline & $\begin{array}{l}\text { Solidago } \\
\quad \text { virgaurea }\end{array}$ & $5.1( \pm 0.5)^{\mathrm{b}}$ & \\
\hline & $\begin{array}{l}\text { Solidago } \\
\quad \text { gigantea }\end{array}$ & $3.8( \pm 0.5)^{\mathrm{a}}$ & \\
\hline \multirow[t]{4}{*}{$\begin{array}{l}\text { Fruits with removed } \\
\text { pappus }\end{array}$} & $\begin{array}{l}\text { Solidago } \\
\quad \times \text { niederederi }\end{array}$ & $3.6( \pm 0.3)$ & \multirow[t]{4}{*}{$\mathrm{H}=7.3^{\mathrm{ns}}$} \\
\hline & $\begin{array}{l}\text { Solidago } \\
\quad \text { canadensis }\end{array}$ & $4.2( \pm 0.6)$ & \\
\hline & $\begin{array}{l}\text { Solidago } \\
\quad \text { virgaurea }\end{array}$ & $4.4( \pm 0.3)$ & \\
\hline & $\begin{array}{l}\text { Solidago } \\
\quad \text { gigantea }\end{array}$ & $3.8( \pm 0.1)$ & \\
\hline
\end{tabular}

The diverse letters in superscript indicate the significant differences between the taxa differences between the studied taxa in (i) final percentage of germinated seeds, (ii) Timson's index, (iii) mean germination time and (iv) coefficient of velocity in the group of fruits with intact pappus and in the group of fruits with removed pappus. The Mann-Whitney U test was used to check the statistical significance of differences between the two experimental groups of fruits of the studied taxa in (i) final percentage of germinated seeds, (ii) Timson's index, (iii) mean germination time and (iv) coefficient of velocity.

The normal distribution of the untransformed data of fruit morphological traits was tested using the KolmogorovSmirnov test, while the homogeneity of variance was checked using the Levene test at the significance level of $p<0.05$. As the data were consistent with the normal distribution and the variance was homogeneous their analysis was based on the one-way analysis of variance (ANOVA) and the Tukey posthoc test. The aforementioned analysis was applied to test the statistical significance of differences in the number and length of pappus bristles and in the length and the width of fruits between the studied taxa.

\section{Results}

\section{Fruit morphological traits}

Considering the number of pappus bristles and the length of pappus bristle, Solidago $\times$ niederederi was similar to
Table 6 Differences in the mean values $( \pm \mathrm{SD})$ of coefficient of velocity between Solidago $\times$ niederederi, $S$. canadensis, $S$. virgaurea, and $S$. gigantea, in the groups of fruits with intact and removed pappus, on the basis of four replicates of 50 fruits

\begin{tabular}{|c|c|c|c|}
\hline Experimental group & Taxon & $\begin{array}{l}\text { Coefficient of } \\
\text { velocity }\end{array}$ & $\begin{array}{l}\text { Statistical significance level (Kruskal- } \\
\text { Wallis } \mathrm{H} \text { test) }\end{array}$ \\
\hline \multirow{4}{*}{$\begin{array}{l}\text { Fruits with intact } \\
\text { pappus }\end{array}$} & $\begin{array}{l}\text { Solidago } \\
\quad \times \text { niederederi }\end{array}$ & $25.2( \pm 1.2)^{\mathrm{ab}}$ & \multirow{4}{*}{$\begin{array}{l}\mathrm{H}=9.5 \\
p \leq 0.05\end{array}$} \\
\hline & $\begin{array}{l}\times \text { niederederi } \\
\text { Solidago } \\
\text { canadensis }\end{array}$ & $23.0( \pm 2.1)^{\mathrm{ab}}$ & \\
\hline & $\begin{array}{l}\text { Solidago } \\
\quad \text { virgaurea }\end{array}$ & $19.8( \pm 11.7)^{\mathrm{a}}$ & \\
\hline & $\begin{array}{l}\text { Solidago } \\
\quad \text { gigantea }\end{array}$ & $26.6( \pm 3.6)^{\mathrm{b}}$ & \\
\hline \multirow[t]{4}{*}{$\begin{array}{l}\text { Fruits with removed } \\
\text { pappus }\end{array}$} & $\begin{array}{l}\text { Solidago } \\
\quad \times \text { niederederi }\end{array}$ & $27.8( \pm 2.3)$ & \multirow[t]{4}{*}{$\mathrm{H}=7.2^{\mathrm{ns}}$} \\
\hline & $\begin{array}{l}\text { Solidago } \\
\quad \text { canadensis }\end{array}$ & $24.3( \pm 3.3)$ & \\
\hline & $\begin{array}{l}\text { Solidago } \\
\quad \text { virgaurea }\end{array}$ & $22.9( \pm 1.2)$ & \\
\hline & $\begin{array}{l}\text { Solidago } \\
\quad \text { gigantea }\end{array}$ & $26.1( \pm 0.7)$ & \\
\hline
\end{tabular}

The diverse letters in superscript indicate the significant differences between the taxa 
Table 7 Differences in the mean values $( \pm \mathrm{SD})$ of final percentage of germinated seeds between the groups of fruits with intact and removed pappus in Solidago $\times$ niederederi, $S$. canadensis, $S$. virgaurea, and $S$. gigantea, on the basis of four replicates of 50 fruits

\begin{tabular}{|c|c|c|c|}
\hline Taxon & $\begin{array}{l}\text { Experimental group (A - fruits } \\
\text { with intact pappus, } \mathrm{B} \text { - fruits } \\
\text { with removed pappus) }\end{array}$ & $\begin{array}{l}\text { Final percentage of } \\
\text { germinated seeds }\end{array}$ & $\begin{array}{l}\text { Statistical significance level } \\
\text { (Mann-Whitney U test) }\end{array}$ \\
\hline Solidago $\times$ niederederi & $\begin{array}{l}\text { A } \\
\text { B }\end{array}$ & $\begin{array}{l}67.0( \pm 5.0) \\
64.5( \pm 9.3)\end{array}$ & $\begin{array}{l}\mathrm{U}=7.0 \\
p=0.88\end{array}$ \\
\hline Solidago canadensis & $\begin{array}{l}\mathrm{A} \\
\mathrm{B}\end{array}$ & $\begin{array}{l}60.0( \pm 2.8) \\
47.5( \pm 1.9)\end{array}$ & $\begin{array}{l}\mathrm{U}=0.5 \\
p \leq 0.05\end{array}$ \\
\hline Solidago virgaurea & $\begin{array}{l}\mathrm{A} \\
\mathrm{B}\end{array}$ & $\begin{array}{l}71.0( \pm 5.0) \\
82.0( \pm 9.1)\end{array}$ & $\begin{array}{l}\mathrm{U}=3.0 \\
p=0.19\end{array}$ \\
\hline Solidago gigantea & $\begin{array}{l}\text { A } \\
\text { B }\end{array}$ & $\begin{array}{l}91.0( \pm 3.5) \\
68.5( \pm 7.2)\end{array}$ & $\begin{array}{l}\mathrm{U}=0.5 \\
p \leq 0.05\end{array}$ \\
\hline
\end{tabular}

$S$. gigantea but it differed significantly from its parental species (Table 2). Moreover, there were significant differences between the studied taxa in the length of cypsela (Table 2). On the other hand, the width of cypsela in the hybrid was similar to that observed in $S$. canadensis and S. gigantea (Table 2). Solidago virgaurea had the greatest number of pappus bristles, the longest pappus bristles and the largest size of cypselae, whereas the lowest number of pappus bristles, the shortest pappus bristles and the smallest size of the cypselae were found in S. canadensis (Table 2).

\section{Seed germination test results}

In both experimental groups (fruits with intact pappus and fruits with removed pappus), there were significant differences between the hybrid, parental species and Solidago gigantea in the final percentage of germinated seeds (Table 3) and Timson's index (Table 4). However, considering the mean germination time (Table 5) and the coefficient of velocity (Table 6) the significant differences between the taxa were found only in the group of fruits with intact pappus. In the group of fruits with intact pappus, the highest and the lowest percentage of germinated seeds was achieved by $S$. gigantea and $S$. canadensis, respectively, whereas in the group of fruits with removed pappus, it was achieved by $S$. virgaurea and $S$. canadensis, respectively (Table 3). Moreover, in the group of fruits with intact pappus, the fastest seed germination was noticed in S. gigantea (Tables 4, 5 and 6), whereas the slowest seed germination occurred in $S$. canadensis (Table 4) and S. virgaurea (Tables 5 and 6). In the group of fruits with removed pappus, the fastest and the slowest seed germination occurred in $S$. virgaurea and S. canadensis, respectively (Table 4).

According to the Mann-Whitney $U$ test results, the studied taxa showed the differences in germination parameters between the groups of fruits with intact and removed pappus. The final percentage of germinated seeds was remarkably greater in the group of fruits with intact pappus than in the group of fruits without the pappus in $S$. canadensis $(p \leq 0.05)$ and $S$. gigantea $(p \leq 0.05)$, whereas in $S$. ×niederederi and $S$. virgaurea it did not differ between the two experimental groups (Table 7). In $S$. virgaurea, fruits with intact pappus presented the significantly lower value of Timson's index than the fruits without the pappus

Table 8 Differences in the mean values $( \pm \mathrm{SD})$ of Timson's index between the groups of fruits with intact and removed pappus in Solidago $\times$ niederederi, S. canadensis, $S$. virgaurea, and $S$. gigantea, on the basis of four replicates of 50 fruits

\begin{tabular}{|c|c|c|c|}
\hline Taxon & $\begin{array}{l}\text { Experimental group ( } \mathrm{A}-\text { fruits } \\
\text { with intact pappus, } \mathrm{B} \text { - fruits with } \\
\text { removed pappus) }\end{array}$ & Timson's index & $\begin{array}{l}\text { Statistical significance level } \\
\text { (Mann-Whitney U test) }\end{array}$ \\
\hline Solidago $\times$ niederederi & $\begin{array}{l}\mathrm{A} \\
\mathrm{B}\end{array}$ & $\begin{array}{l}472.5( \pm 44.9) \\
473.0( \pm 50.2)\end{array}$ & $\begin{array}{l}\mathrm{U}=7.0 \\
p=0.88\end{array}$ \\
\hline Solidago canadensis & $\begin{array}{l}\text { A } \\
\text { B }\end{array}$ & $\begin{array}{l}411.0( \pm 17.6) \\
325.5( \pm 37.5)\end{array}$ & $\begin{array}{l}\mathrm{U}=0.5 \\
p \leq 0.05\end{array}$ \\
\hline Solidago virgaurea & $\begin{array}{l}\text { A } \\
\text { B }\end{array}$ & $\begin{array}{l}418.5( \pm 8.5) \\
544.0( \pm 50.4)\end{array}$ & $\begin{array}{l}\mathrm{U}=0.5 \\
p \leq 0.05\end{array}$ \\
\hline Solidago gigantea & $\begin{array}{l}\mathrm{A} \\
\mathrm{B}\end{array}$ & $\begin{array}{l}650.5( \pm 40.4) \\
493.0( \pm 53.7)\end{array}$ & $\begin{array}{l}\mathrm{U}=0.5 \\
p \leq 0.05\end{array}$ \\
\hline
\end{tabular}


Table 9 Differences in the mean values $( \pm \mathrm{SD})$ of mean germination time between the groups of fruits with intact and removed pappus in Solidago $\times$ niederederi, S. canadensis, S. virgaurea, and S. gigantea, on the basis of four replicates of 50 fruits

\begin{tabular}{|c|c|c|c|}
\hline Taxon & $\begin{array}{l}\text { Experimental group ( } \mathrm{A} \text { - fruits } \\
\text { with intact pappus, } \mathrm{B} \text { - fruits } \\
\text { with removed pappus) }\end{array}$ & Mean germination time & $\begin{array}{l}\text { Statistical significance level } \\
\text { (Mann-Whitney U test) }\end{array}$ \\
\hline Solidago $\times$ niederederi & $\begin{array}{l}\text { A } \\
\text { B }\end{array}$ & $\begin{array}{l}4.0( \pm 0.2) \\
3.6( \pm 0.3)\end{array}$ & $\begin{array}{l}\mathrm{U}=3.0 \\
p=0.19\end{array}$ \\
\hline Solidago canadensis & $\begin{array}{l}\text { A } \\
\text { B }\end{array}$ & $\begin{array}{l}4.1( \pm 0.1) \\
4.2( \pm 0.6)\end{array}$ & $\begin{array}{l}\mathrm{U}=8.0 \\
p=0.96\end{array}$ \\
\hline Solidago virgaurea & $\begin{array}{l}\text { A } \\
\text { B }\end{array}$ & $\begin{array}{l}5.1( \pm 0.5) \\
4.4( \pm 0.3)\end{array}$ & $\begin{array}{l}\mathrm{U}=1.0 \\
p=0.06\end{array}$ \\
\hline Solidago gigantea & $\begin{array}{l}\mathrm{A} \\
\mathrm{B}\end{array}$ & $\begin{array}{l}3.8( \pm 0.5) \\
3.8( \pm 0.1)\end{array}$ & $\begin{array}{l}\mathrm{U}=8.0 \\
p=0.96\end{array}$ \\
\hline
\end{tabular}

$(p \leq 0.05)$. The reversed trend was noticed in $S$. canadensis and $S$. gigantea $(p \leq 0.05)$, whilst fruits of $S$. xniederederi showed similar values of Timson's index in both groups (Table 8). Moreover, seeds of all the studied taxa showed similar values of mean germination time and coefficient of velocity in both experimental groups (Tables 9 and 10).

\section{Discussion}

Based on the results, we can suggest that the length of cypsela is a useful morphological trait that allows distinguishing Solidago $\times$ niederederi from its parental species and $S$. gigantea. Moreover, the number of pappus bristles appears to be an additional diagnostic character of Solidago sect. Solidago nothosubsect. Triplidago to which $S$. × niederederi belongs (Gudžinskas and Žalneravičius 2016). However, this character should be also examined in $S$. $\times$ snarskisii Gudžinskas and Žalneravičius, a hybrid between $S$. gigantea and $S$. virgaurea, which is the second known hybrid of the nothosubsection Triplidago (Gudžinskas and Žalneravičius
2016). Furthermore, our results showing differences in the length of fruits between $S$. ×niederederi and its parental species correspond to previously published data (Migdałek et al. 2014). Similarly, Gudžinskas and Žalneravičius (2016) evidenced significant differences in the length of pappus between S. gigantea and S. virgaurea.

Until now, seed germination of $S$. ×niederederi was tested using the fruits with intact pappus (Pliszko and KostrakiewiczGieralt 2017a, 2017b, 2018a). In this study, we demonstrated that seed germination of the hybrid occurs in fruits with removed pappus as well. The hypothesis that the mechanical removal of pappus decreases the final percentage and speed of seed germination can be fully accepted in $S$. canadensis and $S$. gigantea, whereas in the case of $S$. $\times$ niederederi and $S$. virgaurea it must be rejected. However, the significant differences in the speed of seed germination between two experimental groups in S. canadensis and S. gigantea were confirmed based on the Timson's index only (Table 8). The results of statistical analysis of the mean germination time (Table 9) and coefficient of velocity (Table 10) suggested no effect of pappus removal on the speed of seed germination in all the studied taxa. Furthermore, it is

Table 10 Differences in the mean values $( \pm \mathrm{SD})$ of coefficient of velocity between the groups of fruits with intact and removed pappus in Solidago $\times$ niederederi, S. canadensis, S. virgaurea, and S. gigantea, on the basis of four replicates of 50 fruits

\begin{tabular}{|c|c|c|c|}
\hline Taxon & $\begin{array}{l}\text { Experimental group ( } \mathrm{A} \text { - fruits } \\
\text { with intact pappus, } \mathrm{B} \text { - fruits } \\
\text { with removed pappus) }\end{array}$ & Mean germination time & $\begin{array}{l}\text { Statistical significance level } \\
\text { (Mann-Whitney U test) }\end{array}$ \\
\hline Solidago $\times$ niederederi & $\begin{array}{l}\text { A } \\
\text { B }\end{array}$ & $\begin{array}{l}25.2( \pm 1.2) \\
27.8( \pm 2.3)\end{array}$ & $\begin{array}{l}\mathrm{U}=3.0 \\
p=0.19\end{array}$ \\
\hline Solidago canadensis & $\begin{array}{l}\mathrm{A} \\
\mathrm{B}\end{array}$ & $\begin{array}{l}23.0( \pm 2.1) \\
24.3( \pm 3.3)\end{array}$ & $\begin{array}{l}\mathrm{U}=6.0 \\
p=0.66\end{array}$ \\
\hline Solidago virgaurea & $\begin{array}{l}\mathrm{A} \\
\mathrm{B}\end{array}$ & $\begin{array}{l}19.8( \pm 11.7) \\
22.9( \pm 1.2)\end{array}$ & $\begin{array}{l}\mathrm{U}=1.0 \\
p=0.06\end{array}$ \\
\hline Solidago gigantea & $\begin{array}{l}\mathrm{A} \\
\mathrm{B}\end{array}$ & $\begin{array}{l}26.6( \pm 3.6) \\
26.1( \pm 0.7)\end{array}$ & $\begin{array}{l}\mathrm{U}=8.0 \\
p=0.96\end{array}$ \\
\hline
\end{tabular}


worth mentioning that in other seed germination tests, in which the sand was used as a substrate (Pliszko and KostrakiewiczGieratt 2017a, 2017b, 2018a), the percentage of germinated seeds of the hybrid was higher than that achieved on filter paper in this study. However, the percentage of germinated seeds could be also affected by genetic differences between the hybrid populations from which the fruits have been sampled. Moreover, it is hard to find a well-isolated population of $S$. ×niederederi in the wild and there is a possibility of backcrossing with one or both parental species. The influence of backcrossing on seed germination in the hybrid needs a separate study. In this paper, we focused on the effect of pappus removal on seed germination in relation to general fruit morphology and what is most important is that the hybrid is morphologically intermediate between its parental species (Table 2). At the same time, it is interesting to note that in some species of di- or trimorphic fruits the seed germination percentage is higher in fruits producing the pappus than in those without the pappus. It was observed inter alia in Garhadiolus papposus Boiss. \& Buhse (Sun et al. 2009), Heterotheca subaxillaris var. subaxillaris (Lam.) Britton \& Rusby (Baskin and Baskin 1976), Leontodon longirrostris (Finch \& P.D. Sell) Talavera (de Clavijo 2001), L. saxatilis Lam. (Brändel 2007), Scorzoneroides palisiae (Izuzq.) Greuter \& Talavera, and S. muelleri (Sch. Bip.) Greuter \& Talavera (Cruz-Mazo et al. 2010).

Although the number of pappus bristles and the length of pappus bristle in $S$. $\times$ niederederi and $S$. gigantea were similar (Table 2), the effect of pappus removal on the final percentage of seed germination in these two species was different (Table 7). We assumed that in species of bigger fruits like $S$. $\times$ niederederi and $S$. virgaurea the removal of pappus did not decrease the percentage of germinated seeds as a result of dispersal strategy. During fruit dispersal, long pappus bristles seem to experience more damage than the short ones. In consequence, the loss of pappus bristles enhances the contact of the fruits with the soil and may increase the rate of seed germination. For example, in the case of Symphyopappus reticulatus Baker, if the thick and rigid bristles of the pappus did not separate from the cypsela during dispersal, contact with the substrate would be much more difficult (Marzinek and Oliveira 2010). On the other hand, small fruits could be more sensitive to pathogens after mechanical damage or loss of the pappus. The pappus damage in the effect of insect larvae feeding was observed in several taxa (e.g., Romero and Neto 2005; Winston et al. 2017) and the defensive role of pappus against the attack of herbivores was pointed out by Stuessy and Garver (1996), as well as Bohm and Stuessy (2001). Moreover, de la Peña and Bonte (2014) found that after exposure to aboveground herbivory, Taraxacum officinale produced seeds with longer pappus, increasing dispersal ability. The physiological mechanisms related to the effect of pappus removal on seed germination in Solidago should be explored in accordance with the micromorphology and anatomy of their fruits as it was performed in the case of Taraxacum officinale (Hale et al. 2010). Moreover, it would be worthwhile to test the involvement of twin hairs, which are found on the fruit surface of Solidago species, in fruit hydration and seed germination. Interestingly, De-Paula et al. (2015) proved that the twin hairs on the fruit surface of Emilia fosbergii Nicolson constitute the main passage for water intake, which is essential for seed imbibition and germination, and after imbibition, they release mucilage that can adhere the diaspore.

Production of numerous fruits, which are easily dispersed by wind, is one of the most important factors facilitating naturalization and invasion of $S$. canadensis and S. gigantea (e.g., Huang et al. 2007; Bochenek et al. 2016). The successful establishment of $S$. $\times$ niederederi also depends on fruit production (Pliszko and Kostrakiewicz-Gierałt 2017b). Similarly to native $S$. virgaurea, the loss of pappus bristles does not affect seed germination in the hybrid. What is more, after pappus removal, the percentage of seed germination in the hybrid is still relatively high (Table 2 ). The ability of seed germination after mechanical damage or loss of the pappus bristles seems to be beneficial for $S$. $\times$ niederederi establishment since its seed set is usually limited (Migdałek et al. 2014).

\section{Conclusions}

Solidago $\times$ niederederi differs from its parental species and $S$. gigantea in the length of cypselae. It appears that the small size of the cypselae could be responsible for the negative effect of pappus removal on seed germination. However, further investigations are needed to reveal the importance of pappus and other fruit structures in seed germination in Solidago species.

Acknowledgments We would like to thank the reviewers for their helpful comments and corrections on the first version of this paper. We also thank doctor Michał Hubert Wegrzyn for the opportunity to use a Nikon SMZ1500 microscope in his laboratory. The study was financially supported by the Institute of Botany of the Jagiellonian University in Kraków (K/ZDS/007344 and N18/dB/000002).

\section{Compliance with ethical standards}

Conflict of interest The authors declare that they have no conflict of interest.

Open Access This article is licensed under a Creative Commons Attribution 4.0 International License, which permits use, sharing, adaptation, distribution and reproduction in any medium or format, as long as you give appropriate credit to the original author(s) and the source, provide a link to the Creative Commons licence, and indicate if changes were made. The images or other third party material in this article are included in the article's Creative Commons licence, unless indicated otherwise in a credit line to the material. If material is not included in the article's Creative Commons licence and your intended use is not permitted by statutory regulation or exceeds the permitted use, you will need to obtain 
permission directly from the copyright holder. To view a copy of this licence, visit http://creativecommons.org/licenses/by/4.0/.

\section{References}

Al-Mudaris MA (1998) Notes on various parameters recording the speed of seed germination. Der Tropenlandwirt Beiträge zur tropischen Landwirtschaft und Veterinärmedizin 99:147-154

Baskin JM, Baskin CC (1976) Germination dimorphism in Heterotheca subaxillaris var. subaxillaris. Bull Torrey Bot Club 103:201-206

Baskin CC, Baskin JM (2014) Seeds: ecology, biogeography and evolution of dormancy and germination, 2nd edn. Academic Press/ Elsevier, San Diego

Bochenek A, Synowiec A, Kondrat B, Szymczak M, Lahuta LB, Gołaszewski J (2016) Do the seeds of Solidago gigantea Aiton have physiological determinants of invasiveness? Acta Physiol Plant 38: 159. https://doi.org/10.1007/s11738-016-2179-6

Bohm BA, Stuessy TF (2001) Flavonoids of the sunflower family (Asteraceae). Springer-Verlag, Wien

Brändel M (2007) Ecology of achene dimorphism in Leontodon saxatilis. Ann Bot 100:1189-1197

Burton R (1980) Solidago ×niederederi Khek in Britain. Watsonia 13: $123-124$

Cruz-Mazo G, Narbona E, Buide ML (2010) Germination patterns of dimorphic achenes in three related species of Scorzoneroides (Asteraceae, Lactuceae) growing in different environments. Ann Bot Fenn 47:337-345

de Clavijo ER (2001) The role of dimorphic achenes in the biology of the annual weed Leontodon longirrostris. Weed Res 41:275-286

de la Peña E, Bonte D (2014) Above- and belowground herbivory jointly impact defense and seed dispersal traits in Taraxacum officinale. Ecol Evol 4:3309-3319. https://doi.org/10.1002/ece3.1172

De-Paula OC, Marzinek J, Oliveira DM, Paiva ÉA (2015) Roles of mucilage in Emilia fosbergii, a myxocarpic Asteraceae: efficient seed imbibition and diaspore adhesion. Am J Bot 102:1413-1421. https://doi.org/10.3732/ajb.1500317

Frangiote-Pallone S, de Souza LA (2014) Pappus and cypsela ontogeny in Asteraceae: structural considerations of the tribal category. Rev Mex Biodivers 85:62-77. https://doi.org/10.7550/rmb.32809

Gudžinskas Z, Petrulaitis L (2016) New alien plant species recorded in the southern regions of Latvia. Bot Lith 22:153-160. https://doi.org/ 10.1515/botlit-2016-0016

Gudžinskas Z, Žalneravičius E (2016) Solidago × snarskisii nothosp. nov. (Asteraceae) from Lithuania and its position in the infrageneric classification of the genus. Phytotaxa 253:147-155. https://doi.org/10. 11646/phytotaxa.253.2.4

Hale AN, Imfeld SM, Hart CE, Gribbins KM, Yoder JA, Collier MH (2010) Reduced seed germination after pappus removal in the north American dandelion (Taraxacum officinale; Asteraceae). Weed Sci 58:420-425. https://doi.org/10.1614/WS-D-10-00036.1

Hood JLA, Semple JC (2003) Pappus variation in Solidago (Asteraceae: Astereae). Sida 20:1617-1630

Huang H, Guo S, Chen G (2007) Reproductive biology in an invasive plant Solidago canadensis. Front Biol China 2:196-204

Jaźwa M, Jęrrzejczak E, Klichowska E, Pliszko A (2018) Predicting the potential distribution area of Solidago $\times$ niederederi (Asteraceae). Turk J Bot 42:51-56. https://doi.org/10.3906/bot-1703-17

Karpavičienė B, Radušienė J (2016) Morphological and anatomical characterization of Solidago $\times$ niederederi and other sympatric Solidago species. Weed Sci 64:61-70. https://doi.org/10.1614/WS-D-1500066.1
Marzinek J, Oliveira DMT (2010) Structure and ontogeny of the pericarp of six Eupatorieae (Asteraceae) with ecological and taxonomic considerations. An Acad Bras Ciênc 82:279-291

Migdałek G, Kolczyk J, Pliszko A, Kościńska-Pająk M, Słomka A (2014) Reduced pollen viability and achene development in Solidago $\times$ niederederi Khek from Poland. Acta Soc Bot Pol 83:251-255. https://doi.org/10.5586/asbp.2014.025

Mukherjee SK, Nordenstam B (2008) Diversity of pappus structure in some tribes of the Asteraceae. Phytotaxonomy 8:32-46

Nesom GL (1993) Taxonomic infrastructure of Solidago and Oligoneuron (Asteraceae: Astereae) and observations on their phylogenetic position. Phytologia 75:1-44

Nesom GL (2000) Generic conspectus of the tribe Astereae (Asteraceae) in North America and Central America, the Antilles, and Hawaii. Sida Bot Misc 20:1-100

Nilsson A (1976) Spontana gullrishybrider (Solidago canadensis $\times$ virgaurea) i Sverige och Danmark. Sven Bot Tidskr 70:7-16

Orchard T (1977) Estimating the parameters of plant seedling emergence. Seed Sci Technol 5:61-69

Pagitz K (2016) Solidago $\times$ niederederi $(S$. canadensis $\times S$. virgaurea ssp. virgaurea) in the eastern Alps. In: Ries C and Krippel Y (eds) Biological invasions: interactions with environmental change. Book of abstracts. NEOBIOTA $2016-9^{\text {th }}$ international conference on biological invasions. Vianden, Luxembourg, pp 194

Pliszko A (2015) Neotypification of Solidago $\times$ niederederi (Asteraceae). Phytotaxa 230:297-298. https://doi.org/10.11646/phytotaxa.230.3. 10

Pliszko A, Kostrakiewicz-Gierałt K (2017a) Seed germination in Solidago $\times$ niederederi (Asteraceae) and its parental species after two different fruit storage periods. Biodiv Res Conserv 48:19-24. https://doi.org/10.1515/biorc-2017-0013

Pliszko A, Kostrakiewicz-Gierałt K (2017b) Resolving the naturalization strategy of Solidago $\times$ niederederi (Asteraceae) by the production of generative ramets and seedlings. Plant Ecol 218:1243-1253. https:// doi.org/10.1007/s11258-017-0762-6

Pliszko A, Kostrakiewicz-Gierałt K (2018a) Effect of cold stratification on seed germination in Solidago $\times$ niederederi (Asteraceae) and its parental species. Biologia 73:945-950. https://doi.org/10.2478/ s11756-018-0113-7

Pliszko A, Kostrakiewicz-Gierałt K (2018b) Flower-visiting insects on Solidago $\times$ niederederi (Asteraceae): an observation from a domestic garden. Botanica 24:162-171. https://doi.org/10.2478/botlit-20180016

Pliszko A, Kostrakiewicz-Gierałt K (2019) The importance of sexual, asexual, and mixed ramet clusters in production of descendant ramets in populations of Solidago $\times$ niederederi (Asteraceae). Biologia 74:953-960. https://doi.org/10.2478/s11756-00233-y

Pliszko A, Zalewska-Gałosz J (2016) Molecular evidence for hybridization between invasive Solidago canadensis and native $S$. virgaurea. Biol Invasions 18:3103-3108. https://doi.org/10.1007/s10530-0161213-3

Pliszko A, Łazarski G, Kalinowski P, Adamowski W, Rutkowski L, Puchałka R (2017) An updated distribution of Solidago $\times$ niederederi (Asteraceae) in Poland. Acta Mus Siles Sci Natur 66: 253-258. https://doi.org/10.1515/cszm-2017-0026

Pliszko A, Adamowski W, Pagitz K (2019) New distribution records of Solidago $\times$ niederederi (Asteraceae) in Austria, Italy, and Poland. Acta Mus Siles Sci Natur 68:195-199. https://doi.org/10.2478/ cszm-2019-0020

Radušienė J, Marksa M, Karpavičienė B (2018) Assessment of Solidago $\times$ niederederi origin based on the accumulation of phenolic compounds in plant raw materials. Weed Sci 66:324-330. https://doi. org/10.1017/wsc. 2018.8

Romero GQ, Neto JV (2005) Flowering phenology, seed set and arthropod guilds in Trichogoniopsis adenantha (DC) (Asteraceae) in south-East Brazil. Rev Bras Bot 28:171-178 
Semple JC (2020) Solidago. Astereae Lab. https://uwaterloo.ca/astereaelab/research/goldenrods. Accessed 18 Feb 2020

Semple JC, Cook RE (2006) Solidago L. In: Flora North America editorial committee (eds) Flora of North America north of Mexico, vol. 20(2). Oxford University Press, New York, pp 107-166

Shaukat SS, Siddiqui IA, Ali Z, Sikander S (2004) Fecundity and factors regulating germination of Vernonia cinerascens and $V$. cinerea. Int $\mathrm{J}$ Biol Biotechnol 1:279-291

Silva TDG, Marzinek J, Hattori EKO, Nakajima JN, De-Paula OC (2018) Comparative cypsela morphology in Disynaphiinae and implications for their systematics and evolution (Eupatorieae: Asteraceae). Bot J Linn Soc 186:89-107. https://doi.org/10.1093/botlinnean/ box 082

Small J (1918) The origin and development of the Compositae. Chapter V. The pappus. New Phytol 17:69-94

Stace CA, Preston CD, Pearman DA (2015) Hybrid flora of the British Isles. Botanical Society of Britain and Ireland, Bristol

Stuessy TF, Garver D (1996) The defensive role of pappus in heads of Compositae. In: Caligari PDS, Hind DJN (eds) Compositae: biology and utilization. Proceedings of the International Compositae
Conference, Kew1994, vol 2. The Royal Botanic Gardens, Kew, pp 81-91

Sun HZ, Lu JJ, Tan DY, Baskin JM, Baskin CC (2009) Dormancy and germination characteristics of the trimorphic achenes of Garhadiolus papposus (Asteraceae), an annual ephemeral from the Junggar Desert, China. S Afr J Bot 75:537-545

Sunding P (1989) Naturaliserte Solidago-(gullris-) arter i Norge. Blyttia 47:23-27

Talukdar T (2015) Cypselas diversity as novel taxonomic marker in the tribe Astereae (family Asteraceae). Emer Life Sci Res 1:26-34

Timson J (1965) New method of recording germination data. Nature 207: 216-217

Winston RL, Randall CB, Blossey B, Tipping PW, Lake EC, HoughGoldstein J (2017) Field guide for the biological control of weeds in eastern North America. USDA Forest Service, Forest Health Technology Enterprise Team, Morgantown, West Virginia

Publisher's note Springer Nature remains neutral with regard to jurisdictional claims in published maps and institutional affiliations. 